\title{
Krzysztof BIERNAT*
}

\section{Wybrane pojęcia stosowane w naukach o środowisku i ich interpretacja}

Rozwój cywilizacyjny ludzkości jest nośnikiem zarówno postępu, w tym technicznego, kulturowego, w naukach medycznych i wielu innych, ale jednocześnie stanowi zagrożenie w zakresie stanu środowiska naturalnego i wielkości zasobów przyrody, którymi może dysponować człowiek. Niekontrolowany rozwój cywilizacyjny przy niewłaściwej gospodarce zasobami naturalnymi spowodować może występowanie sprzężeń zwrotnych zagrażających nawet egzystencji człowieka jako gatunku.

Stąd też zachowanie stanu środowiska, z jednoczesnym działaniem na rzecz jego poprawy, wymaga poznania i zrozumienia wielu problemów o interdyscyplinarnym charakterze, ogólnie mieszczących się $\mathrm{w}$ obszarach wiedzy o środowisku.

W ostatnich latach nastąpił znaczny wzrost zainteresowania środowiskiem, a dokładniej wpływem człowieka i jego działalności na stan tego środowiska. Problemy $\mathrm{z}$ tym związane stanowiły i dalej stanowią przedmiot rozważań teoretycznych i badań w wielu dziedzinach i dyscyplinach naukowych, zarówno podstawowych, jak i stosowanych. Do niedawna wszelkie prace $\mathrm{w}$ tym zakresie prowadzone jednak były oddzielnie $\mathrm{w}$ poszczególnych dziedzinach, co spowodowało powstanie różnych definicji i pojęć nie zawsze kompatybilnych, powodując powstawanie nieścisłości lub nawet nieporozumień. Zaistniała więc konieczność interdyscyplinarności $\mathrm{w}$ rozwiązywaniu zagadnień związanych $\mathrm{z}$ egzystencją $\mathrm{i}$ rozwojem ludzkości $w$ otaczającym ją świecie $w$ celu jednoczesnego uwzględniania możliwie wszystkich czynników wpływających na rozwój cywilizacyjny, bez czynienia szkody środowisku, a zatem sobie samym.

Nauka polska, zajmując się problematyką środowiska i jego ochroną, ma $\mathrm{w}$ tej materii pewne, znaczące osiągnięcia wynikające między innymi $\mathrm{z}$ interdyscyplinarnego, systemowego ujmowania tej problematyki. Ujęcie to obejmuje już postępy $z$ dziedzin nauk technicznych, przyrodniczych, humanistycznych, w tym ekonomicznych i prawnych łącznie, co pozwala lepiej precyzować złożoność zagadnień i opracowywać algorytmy postępowania dla dziedzin stosowanych.

* Szkoła Glówna Slużby Pożarniczej w Warszawie. 
Zatem dla jednoznacznego definiowania i interpretowania podstawowych pojęć, celowe jest uporządkowanie tych pojęć stosowanych powszechnie, a czasami niepoprawnie w naukach o środowisku.

$\mathrm{W}$ potocznym rozumieniu zagadnień związanych $\mathrm{z}$ ochroną środowiska nadmiernie i bardzo często niepoprawnie nadużywany jest termin „ekologia”. Termin ten wraz z definicją tej dziedziny nauki został wprowadzony przez E. Haeckla w 1866 roku i uściślony w roku 1895 przez S.A. Forbesa. Od tych czasów przez ekologię należy rozumieć naukę, z dziedziny nauk przyrodniczych, a dokładniej biologicznych, badająca wzajemne stosunki pomiędzy organizmami, a otaczającym je środowiskiem. Stosunki te wynikają z praw przyrody, które są niezmienne i ściśle określone. Prawa te działały, działaja i będą działać dalej, niezależnie od woli człowieka, stąd też ingerencja człowieka w zakresie prób zmian tych stosunków lub ich modyfikacji może jedynie spowodować szkody w środowisku lub nawet doprowadzić do katastrofy ekologicznej. Środowisko lub jego elementy stanowią bowiem zbiór pewnych układów otwartych $z$ punktu widzenia termodynamicznego i mogą wymieniać $z$ otoczeniem masę i energię, przy czym należy pamiętać także o tożsamości masy i energii. Każdy układ dąży do osiągnięcia stanu równowagi, regulowanego odpowiednimi stosunkami pomiędzy elementami środowiska, który charakteryzuje się między innymi możliwie małą energią wewnętrzną i możliwie dużym stopniem nieuporządkowania (entropią). Zaburzanie równowagi układu przez czynniki zewnętrzne, zgodnie $z$ zasada przekory (zasada Le Chattelier-Browna) wywołuje w tym układzie takie zmiany, które prowadzą do zmniejszenia lub zniwelowania oddziaływania tych czynników. Ponieważ równowagę przyrodniczą zaburza człowiek i jego działalność to środowisko jako układ modyfikuje się zgodnie z prawami określanymi w ekologii tak, aby zmniejszyć skutki tego zaburzania. Nadmierna ingerencja człowieka w układy środowiskowe może spowodować wyczerpanie się możliwości obronnych tych układów, zgodnie z zasadą przekory i wówczas układ taki dążyć będzie do osiągania następnego możliwego stanu równowagi, co skutkować może całkowicie odmiennymi bilansami masy i energii, które mogą prowadzić do powstawania katastrof ekologicznych.

W związku z powyższym w Polsce i coraz częściej na świecie, dziedziną wiedzy zajmującą się szeroko rozumianą ochroną środowiska jest sozologia. Nazwę tą pochodzącą od greckiego słowa "sodzo”, co znaczy "ochraniać", "ratować", „pomagać" wprowadził do terminologii światowej polski uczony Walery Goetel. Istnieje kilka równoznacznych definicji sozologii. Jedna z nich jest definicja sformułowana przez J.M. Dołęge, definiująca sozologię jako dziedzinę wiedzy badającą i określającą możliwości i metody systemowej ochrony biosfery, czyli środowiska przed destrukcyjnym oddziaływaniem antroposfery, czyli człowieka i jego dzia- 
łalności. A więc to sozologia jest tą dziedziną wiedzy, która obejmuje wszelkie aspekty ochrony środowiska obejmujące zbiory zagadnień filozoficznych, etycznych, edukacyjnych, psychologicznych, medycznych, prawnych, ekonomicznych, technicznych i technologicznych, a także inżynierii materiałowej, chemicznej, transportu, budownictwa, zarządzania tymi dziedzinami, itp.

W obiegowym pojęciu, w zakresie praw ekologii i sozologii istnieje wiele niepoprawnych, nadużywanych lub nieścisłych pojęć. To takich pojęć zaliczyć należy pojęcie „zrównoważonego rozwoju” i „energii odnawialnej".

Zrównoważony rozwój jest terminem wprowadzonym do języka polskiego, a pochodzącym $\mathrm{z}$ niepoprawnego tłumaczenia terminu angielskiego "sustainable development". Słowo "sustained” mające wiele znaczeń, oznacza: „trwały”, „nieprzerwany”, „długotrwały”, „przedłużony” itp., a słowo „sustain” oznacza dosłownie i w przenośni "podtrzymać" i „podtrzymywać". Terminologia angielska w petni odpowiada przypisanemu znaczeniu, natomiast tłumaczenie polskie jest nieprecyzyjne, a nawet niepoprawne $\mathrm{z}$ punktu widzenia chociażby termodynamiki chemicznej. Jak już wspomniano, każdy układ, w pewien sposób rozwijając się, dąży do uzyskania stanu równowagi. Stan równowagi jest więc antyteza rozwoju. W rzeczywistości, w tak zwanych układach rzeczywistych osiąganie stanu równowagi przeważnie nie jest możliwe, stąd układy te osiągają równowagi chwiejne lub chwilowe, przechodząc do kolejnych stanów równowagowych. Stąd też poprawne pojęcie "sustainable development" należy interpretować jako rozwój trwały, ale zapewniający pełną możliwość regeneracji środowiska, realizowaną samoczynnie lub podtrzymywaną przez racjonalne działanie człowieka.

$\mathrm{Z}$ kolei pojęcie „energia odnawialna" jest zaprzeczeniem drugiej zasady termodynamiki. Energia nigdy sama się bowiem nie odnawia, ani też nigdy nie ginie, a jedynie zmienia swoje formy. W pewnym sensie każda formę energii, którą się uda zmagazynować, można uznać w ten sposób za odnawialną, ponieważ po wyczerpaniu się zapasu tej zmagazynowanej energii można ponownie ten zbiornik uzupełnić. Tak rozumując można stwierdzić, że silniki samochodowe zasilane są także energią odnawialną, ponieważ po wyczerpaniu się zapasu paliwa (energii chemicznej zawartej $w$ tym paliwie), na najbliższej stacji paliwowej można energię odnowić, uzupełniając paliwo. Procesy przyrodnicze, w tym procesy geotermiczne zachodzą w sposób ciągły, co oznacza że wszelkie znane surowce mogą być wytwarzane w tych warunkach także w sposób ciągły, a zatem moga być również uznawane za odnawialne. Należy więc potoczne kryterium odnawialności surowców rozumieć jako nadążanie $z$ produkcją przez przyrodę tych surowców z wydajnością co najmniej odpowiadającą ich zużywaniu w działalności człowieka, zaś zamiast pojęcia 
„energia odnawialna” stosować poprawniej pojęcie „energia ze źródeł naturalnych" lub „energia przyrodnicza”.

W terminologii sozologicznej używane jest także wiele innych pojęć i definicji. Dla zachowania zatem wspólnego języka we wszystkich dyscyplinach zajmujących się środowiskiem poniżej proponuje się definiować podstawowe pojęcia w następujący sposób:

- atmosfera jest to powłoka gazów otaczająca kulę ziemską, składająca się głownie z azotu, tlenu oraz śladowych ilości gazów szlachetnych, ditlenku węgla i wodoru. Skład atmosfery utrzymywany jest w równowadze oddziaływaniami energetycznymi z przestrzeni kosmicznej i biosfery. Atmosfera stanowi jedno z podstawowych źródeł życia i zabezpiecza biosferę przed promieniowaniem kosmicznym i słonecznym;

- antroposfera charakteryzuje czas i miejsce występowania człowieka oraz całą jego działalność;

- antropopresja jest to oddziaływanie człowieka i wytworów jego działalności na środowisko naturalne;

- biosfera stanowi obszar występowania form ożywionych na Ziemi i obejmuje powierzchnię Ziemi (pedosferę), górną warstwę litosfery, dolną warstwę atmosfery oraz hydrosferę;

- siderosfera stanowiąca według Goldschmidta żelazne jądro Ziemi, wewnątrz której w wyniku kondensacji skoncentrowały się pierwiastki z grupy żelazowców, platynowców oraz złoto, zwane pierwiastkami siderofilnymi;

- chalkosfera, następna sfera Ziemi po siderosferze, stanowiąca sferę siarczkowo-tlenkową, w której skoncentrowały się pierwiastki chalkofilne: miedziowce, cynkowce, borowce, węglowce bez węgla i krzemu, azotowce bez azotu oraz tlenowce bez tlenu;

- biocenoza stanowi zespół organizmów żywych w danym środowisku, powiązanych ze sobą czynnikami ekologicznymi, tworzący pewną organiczną całość będącą w stanie równowagi dynamicznej;

- ekosystem jest to zespół współdziałających lub i współzależnych od siebie organizmów znajdujacych się w określonym środowisku;

- fenotyp jest to zespół wszystkich cech organizmu, będący wynikiem współdziałania genotypu i warunków środowiskowych;

- gleba jest to powierzchniowa warstwa skorupy ziemskiej powstała ze skał macierzystych, zmieszana z rozkładającymi się cząstkami roślin i zwierząt;

- genotyp jest to zespół genów danego organizmu warunkujący jego właściwości dziedziczne;

- hydrosfera jest to wodna powłoka Ziemi, znajdująca się zarówno w litosferze jak i atmosferze, stanowiąca wody mórz, oceanów, rzek, wody podziemne, lodowce i parę wodną oraz deszcze, śnieg, grad i wody osadowe; 
- klimat jest zespół warunków atmosferycznych występujący w danym rejonie i utrzymujący się przez dłuższy czas;

- kosmosfera jest to najbliższe kosmiczne otoczenie Ziemi, łącznie $\mathrm{z}$ atmosferą;

- litosfera stanowi stałą część skorupy ziemskiej o grubości do 50-200 $\mathrm{km}$, dostępnej do $16 \mathrm{~km}$, w której zgromadzone są pierwiastki litofilne, to jest: litowce, berylowce, skandowce, tytanowce, wanadowce i chromowce;

- pierwiastki litofilno-atmofilne sa to pierwiastki skondensowane $\mathrm{w}$ górnej warstwie litosfery oraz $\mathrm{w}$ atmosferze, zwane pierwiastkami litofilno-atmofilnymi i stanowią pierwiastki takie jak: wodór, azot, tlen, fluorowce i gazy szlachetne oraz węgiel i krzem;

- smog jest to termin określający zanieczyszczenie powietrza, pochodzący od angielskiego "smoke" - dym i "fog" - mgła. Rozróżnia się smog kwaśny (zanieczyszczenie pierwotne), zwany londyńskim oraz smog fotochemiczny (zanieczyszczenie wtórne), zwany także smogiem typu Los Angeles;

- smog fotochemiczny jest to smog stanowiący zanieczyszczenie wtórne, po raz pierwszy zidentyfikowany w Los Angeles w czasie drugiej wojny światowej. Podstawowe reakcje zachodzące $w$ tym przypadku polegają na rozkładzie ditlenku azotu powstającego $\mathrm{w}$ wyniku spalania paliw ciekłych $w$ atmosferze powietrza $w$ komorach spalania $w$ wysokiej temperaturze. Ditlenek ten jest rozkładany przy pomocy światła słonecznego o długości fali poniżej $310 \mathrm{~nm}$ (fotonami, jako nośnikami o energii równej wartości hn (h - stała Plancka, n - częstotliwość fali) każdy, w myśl reakcji:

$$
\mathrm{NO}_{2(\mathrm{~g})}+\mathrm{hv} \rightarrow \mathrm{O}_{(\mathrm{g})}+\mathrm{NO}_{(\mathrm{g})}
$$

Tlen atomowy reaguje $z$ tlenem cząsteczkowym powodując powstawanie toksycznego ozonu:

$$
\mathrm{O}_{(\mathrm{g})}+\mathrm{O}_{2(\mathrm{~g})} \rightarrow \mathrm{O}_{3(\mathrm{~g})}+\mathrm{M}_{(\mathrm{g})}
$$

W reakcji tej symbol $\mathrm{M}$ oznacza substancję odbierającą nadmiar energii powstającej $\mathrm{w}$ wyniku reakcji. Substancją tą stanowi $\mathrm{z}$ zasady tlen lub azot zawarty w powietrzu, którego obecność zapobiega rozkładowi ozonu. Następnie ozon reaguje $z$ monotlenkiem azotu powodując ponowne wytworzenie ditlenku azotu, a wówczas ustala się pewien stan równowagi:

$$
\mathrm{O}_{3(g)}+\mathrm{NO}_{(\mathrm{g})} \rightarrow \mathrm{O}_{2(\mathrm{~g})}+\mathrm{NO}_{2(\mathrm{~g})}
$$


W smogu fotochemicznym zachodzą w efekcie reakcje prowadzące do powstawania drażniącego, szczególnie oczy, azotanu nadtlenooctowego (PAN). Głównymi składnikami smogu fotochemicznego są: ozon, ditlenek i monotlenek azotu oraz tlenek węgla, a oprócz działania drażniącego PAN, działa on niszcząco na gumy.

- smog londyński jest to smog o charakterze kwaśnym, po raz pierwszy zidentyfikowany $w$ Londynie, powstający jako efekt niezupełnego spalania paliw, szczególnie kopalnych występujący szczególnie w niskich temperaturach przy niedomiarze tlenu powodujący powstawanie toksycznego tlenku węgla $\mathrm{CO}$ oraz wielopierścieniowych węglowodorów aromatycznych WWA, jako wyniku rozkładu termicznego paliwa. $Z$ racji obecności skondensowanej pary wodnej w postaci mgły i stosunkowo dużego zasiarczenia paliw stałych, najgroźniejszym składnikiem smogu, powodującym znaczne zakwaszenie mgły jest ditlenek siarki powstający w wyniku spalania siarki zawartej w paliwach. Ditlenek siarki rozpuszczając się w kropelkach mgły dysocjuje w myśl reakcji:

$$
\mathrm{SO}_{2(\mathrm{~g})}+\mathrm{H}_{2} \mathrm{O}_{(\mathrm{c})} \rightarrow \mathrm{H}^{+}{ }_{(\mathrm{aq})}+\mathrm{HSO}_{3(\mathrm{aq})^{\prime}}^{-}
$$

gdzie symbol (g) oznacza stan gazowy, (c) stan ciekły, a (aq) -roztwór wodny.

W obecności śladowych zanieczyszczeń metalicznych typu żelazo lub mangan jako katalizatorów następuje wytwarzanie kwasu siarkowego w myśl reakcji jonowej:

$$
2 \mathrm{HSO}_{3(\mathrm{aq})}^{-}+\mathrm{O}_{2(\mathrm{aq})} \rightarrow 2 \mathrm{H}^{+}{ }_{(\mathrm{aq})}+2 \mathrm{SO}_{4(\mathrm{aq})}^{2-}
$$

Powstający kwas siarkowy silnie absorbuje wodę, stąd następuje wzrost kropli mgły, jej gęstnienie i znaczne obniżanie wartości pH (odczyn kwaśny). Głównymi składnikami smogu kwaśnego są: cząstki stałe (pyły, sadza), monotlenek węgla oraz związki siarki (głownie ditlenek), a efektem jego oddziaływania jest podrażnienie górnych dróg oddechowych poprzez $\mathrm{SO}_{2}$ i dym oraz działanie niszczące na stal i materiały zawierające cement.

- stratosfera jest to sucha warstwa atmosfery, rozpoczynająca się na wysokości około $10 \mathrm{~km}$ od powierzchni Ziemi, w której już nie występują zjawiska meteorologiczne;

- system jest to zespół różnych elementów wzajemnie ze sobą powiązanych i wzajemnie oddziaływujących, stanowiących całość według przyjętego kryterium, przy czym używanie pojęcia podsystem w systemie, należy uznawać jako nieprawidłowe;

- środowisko stanowi zespół wszelkich czynników i warunków, w których żyje określony organizm; 
- troposfera jest to najniższa warstwa atmosfery sięgająca do około 10 km wysokości od powierzchni Ziemi.

Działalność człowieka, jak już wspomniano, zakłóca równowagę systemów środowiska. Z pośród wielu elementów zaburzających tą równowagę istotnym procesem jest niszczenie powłoki ozonowej, a także powstawanie smogu. Dla pełnego przybliżenia tych zjawisk należy skrótowo przedstawić podział podstawowych zanieczyszczeń organicznych pochodzenia antropogenicznego $\mathrm{z}$ uwzględnieniem ich negatywnego oddziaływania na środowisko. Stanowią one lotne związki (gazy) emitowane do powietrza atmosferycznego, substancje rozpuszczalne i nierozpuszczalne $\mathrm{w}$ wodzie, zawarte $\mathrm{w}$ ściekach komunalnych, przemysłowych, opadowych i rolniczych oraz substancje rozpuszczalne i nierozpuszczalne $w$ wodzie wymywane poprzez opady atmosferyczne ze składowisk odpadów komunalnych i przemystowych oraz $\mathrm{z}$ terenów rolniczych.

Zasadniczymi, najbardziej niebezpiecznymi dla środowiska są następujące substancje organiczne, charakteryzujące się dużym stopniem trwałości:

- chlorowcopochodne (halogenopodochodne) weglowodorów alifatycznych $\mathrm{C}_{1}, \mathrm{C}_{2}$, głównie chlorofluoroęglowodory ( $\mathrm{CFC}_{\mathrm{s}}$ ) o handlowej nazwie freony oraz bromofluorowęglowodory (BCFC) zwane halonami;

- chlorowane pochodne węglowodorów aromatycznych, głownie: chlorowany benzen (dichloro i trichlorobenzeny), polichlorowane bifenyle i terfenyle oraz dioksyny;

- wielopierścieniowe węglowodory aromatyczne (WWA);

- pestycydy, w tym insektycydy, herbicydy i fungicydy;

- surfakanty (związki powierzchniowo czynne), w tym anionowe, kationowe i amfoteryczne oraz niejonowe.

Freony jako lotne i niepalne substancje, charakteryzujące się dużą prężnością par były wykorzystywane jako media chłodzące w urządzeniach klimatyzacyjnych i lodówkach, jako rozpuszczalniki, aerozole oraz jako substraty do produkcji pianek poliuretanowych i teflonu. Halony, o podobnych właściwościach były i są jeszcze stosowane jako środki gaśnicze. Potencjalna możliwość rozkładu ozonu $w$ atmosferze przez freony i halony określana jest przy pomocy współczynnika ODP (ozone depleting potential). Dla najbardziej aktywnego w niszczeniu warstwy ozonowej freonu CFC-11 (trichlorofluorometan) przyjęto współczynnik ODP równy jedności, podczas gdy halony mają współczynniki ODP osiągające wartości równe 10 (halon 1301). Wartość ODP maleje dla związków o mniejszej trwałości. Udział w niszczeniu warstwy ozonowej mają także tetrachlorometan $\mathrm{i}$ chlorek metylu stosowane $\mathrm{w}$ procesach wytwarzania freonów oraz bromek metylu wytwarzany w naturalnych procesach występujących $\mathrm{w}$ wodach oceanicznych. $\mathrm{W}$ mechanizmach niszczenia war- 
stwy ozonowej, skrótowo opisanych w podręczniku dla chlorofluorowęglowodorów, należy uwzględnić analogiczne mechanizmy odddziaływania na tą warstwę przez halony, jednak intensywniejsze $z$ racji wysokiego ODP oraz konieczność udziału w reakcjach gazowego składnika $\mathrm{M}$, opisanego powyżej (smog fotochemiczny). W stratosferycznych obłokach lodowych, $z$ uwagi na zbyt małe stężenie atomów tlenu, proces destrukcji ozonu zachodzi $\mathrm{z}$ udziałem dimerów rodnika chloru $\mathrm{ClO}^{\circ}$. Dimery te rozkładając się fotolitycznie, przy obecności składnika $M$, rozkładają ozon wyzwalając kolejne dwa rodniki $\mathrm{ClO}^{\circ}$, biorące udział w tworzeniu dimeru i kolejnej reakcji rozkładu oraz tlen cząsteczkowy.

Chlorowany benzen, $\mathrm{w}$ którym atomy wodoru zostały podstawione atomami chloru jest stosowany, najczęściej występujący w postaci di i trichlorobenzenów, występuje w postaci półproduktów i rozpuszczalników $w$ procesach syntezy organicznej. Związki te, odporne na degradację chemiczną i biochemiczną, trwale zanieczyszczają toksycznie glebę oraz wody powierzchniowe i podziemne.

Polichlorowane bifenyle $\left(\mathrm{PCB}_{\mathrm{s}}\right)$ tworzą mieszaninę około 200 różnych izomerów (kongenerów) bifenylu. Związki te, mając właściwości hydrofobowe, mogą gromadzić się na granicy faz woda-powietrze, co ułatwia ich rozkład pod wpływem promieniowania UV. Związki te stosowane są do produkcji olejów elektroizolacyjnych, cieczy hydraulicznych, tworzyw sztucznych i farb, struktura przypominają hormony, stąd też mogą przenikać do receptorów hormonalnych zakłócając endokryniczne mechanizmy organizmów ssaków. Podobnie działają także trudno rozkładalne polichlorowane terfenyle ( $\mathrm{PCT}_{\mathrm{s}}$ ), występujące na ogół łącznie z $\mathrm{PCB}_{\mathrm{s}}$, lecz nieco $w$ mniejszych ilościach. Ulegają one adsorpcji na cząstkach zawiesin w fazie wodnej i w osadach dennych oraz biokumulacji w organizmach wodnych.

Wielopierścieniowe węglowodory aromatyczne (WWA) powstają w wyniku procesów przemysłowych związanych z przeróbką ropy naftowej i węgla, w wyniku spalania paliw ciekłych i stałych, szczególnie przy niezupełnym spalaniu, w wyniku niewłaściwie realizowanych procesach spalania odpadów, a także występują w dymie papierosowym. Kumulują się $\mathrm{w}$ organizmach żywych, wykazując silne działania rakotwórcze.

Pestycydy występują w złożonej strukturalnie postaci głównie organicznej. Stanowią one związki typu:

- chlorowane węglowodory alicykliczne i aromatyczne;

- związki fosforoorganiczne;

- karbaminiany;

- pochodne kwasu fenoksyoctowego;

- pochodne triazyny;

- pochodne mocznika. 
Pestycydy charakteryzują się określoną toksycznością i zdolnością do kumulacji $w$ organizmach żywych. Szczególnie niebezpieczne dla ludzi i zwierząt są nierozpuszczalne $\mathrm{w}$ wodzie, a odkładające się $\mathrm{w}$ tkankach tłuszczowych pestycydy chloroorganiczne. Trwałość pestycydów w środowisku określana jest mianem persystentności. Poza wymienionymi powyżej pestycydami owadobójczymi (insektycydami), chwastobójczymi (herbicydami), i grzybobójczymi (fungicydami) rozróżnia się:

- rodentycydy jako środki gryzoniobójcze;

- bakteriocydy jako środki bakteriobójcze;

- moluskocydy, środki ślimakobójcze;

- nematocydy, środki nicieniobójcze;

- akaracydy, środki roztoczobójcze;

- defolianty, środki do usuwania lisci roślin;

- repelenty, środki odstraszajace szkodniki;

- atraktanty, środki o działaniu nęcącym owady, gryzonie i inne szkodniki;

- konserwanty drewna.

Surfakanty stanowią grupę związków powierzchniowo-czynnych, stanowiących syntetyczne substancje organiczne o budowie asymetrycznej wykazujące zdolność do obniżania napięcia powierzchniowego na granicy faz ciecz-ciało stałe. Surfakanty niejonowe na bazie węglowodanów są nietoksyczne i łatwo ulegają biodegradacji. Natomiast surfakanty jonowe, z wyją̧tkiem estrów wyższych kwasów tłuszczowych (mydeł), stanowiące składniki środków piorących, czyszczących i emulgujących są odporne na biodegradację i zalegają $\mathrm{w}$ środowisku. W procesie biologicznego oczyszczania ścieków niektóre surfakanty niejonowe mogą przekształcać się $w$ metabolity o właściwościach toksycznych. Surfakanty wykazując pewną toksyczność w stosunku do wodnych składników biocenozy, utrudniają dyfuzję tlenu atmosferycznego do zbiorników wodnych, podwyższają rozpuszczalność WWA i $\mathrm{PCB}_{\mathrm{s}^{\prime}}$ a także metali ciężkich, aktywizując działanie zanieczyszczeń $w$ środowisku wodnym.

Istotnym elementem racjonalnego działania, $\mathrm{w}$ zgodności $\mathrm{z}$ prawami ekologii i osiągnięciami mieszczącymi się $\mathrm{w}$ zakresie sozologii systemowej, jest właściwa świadomość ekologiczna. Świadomość ta wymaga posiadania niezbędnej wiedzy przyrodniczej z zakresu wpływu działalności człowieka na stan środowiska. Wiedza ta jest niezbędna do ksztaltowania właściwych relacji pomiędzy człowiekiem i jego działalnością, a otaczającym go środowiskiem. 


\section{Bibliografia}

DOŁEGA J.M., 1998 - Czlowiek w' zagrożonym środowisku", Wydawnictwo ATK, Warszawa. SZPERLIŃSKI Z., 2002 - Chemia w ochronie i inżynierii środowiska”, Cz. I...II, T. 1...2, Wyd. Oficyna Wydawnicza Politechniki Warszawskiej, Warszawa.

NAMIEŚNIK J., JAMRÓGIEWICZ Z., (red.), 1998 - Fizykochemiczne metody kontroli zanieczyszczeń środowiska, Wydawnictwa Naukowo-Techniczne, Warszawa.

NAMIEŚNIKA J., CHRZANOWSKI W., SZPINEK P., (red.), 2002 - Nowe horyzonty $i$ wyzwania $w$ analityce $i$ monitoringu środowiska, Wydawnictwo Centrum Doskonałości Analityki i Monitoringu Środowiskowego Politechniki Gdańskiej, Gdańsk.

ANDREWS J. E., BRIMBLECOMBE P., JICKELLS T. D., LISS P. S., 2000 - Wprowadzenie do chemii środowiska, Wydawnictwa Naukowo-Techniczne, Warszawa.

ALLOWAY B. J., AYRES D. C., 1999 - Chemiczne podstawy zanieczyszczania środowiska, Wydawnictwo Naukowe PWN, Warszawa.

BILITEWSKI B., HÄRDTLE G., MAREK K., 2003 - Podręcznik gospodarki odpadami, Wydawnictwo: Seidel \& Przywecki, Warszawa.

WANDRASZ J. W., BIEGAŃSKA J., 2003 - Odpady niebezpieczne-podstawy teoretyczne, Wydawnictwo Politechniki Śląskiej, Gliwice.

ZAKRZEWSKI S. F., 2000 - Podstawy toksykologii środowiska, Wydawnictwo Naukowe PWN, Warszawa.

O’NEIL P., Chemia środowiska, 2000 - Wydawnictwo Nankowe PWN, Warszawa.

ROSIK-DULEWSKA Cz., 2000 - Podstawy gospodarki odpadami, Wydawnictwo Naukowe PWN, Warszawa.

WEINER J., 2003 - Życie i ewolıcja biosfery, Podręcznik ekologii ogólnej, Wydawnictwo Naukowe PWN, Warszawa.

JOHANSSON A., 1997 - Czysta technologia, Środowisko, Technika, Przyszłośc, Wydawnictwo Naukowo-Techniczne, Warszawa. 